\title{
An On-line Questionnaire Survey on Students' Views and Teachers' Practices in Corrective Feedback in Teaching Chinese to Speakers of Other Languages
}

\author{
Liqin $\mathrm{Wu}^{1}$, Yong $\mathrm{Wu}^{1}$ \& Xiangyang Zhang ${ }^{1}$ \\ ${ }^{1}$ Anhui University of Finance and Economics, Bengbu, Anhui, China \\ Correspondence: Liqin Wu, Languages and Media, AUFE. 962 Caoshan Road, Bengbu, Anhui, China. 233030.
}

Received: December 19, 2020; Accepted: January 3, 2021; Published: January 6, 2021

This research is financially supported by The Key Anhui Humanities and Social Sciences Planned Project Fund (AHSKZ2018D16); and by The Key Scientific Research Fund in Anhui University of Finance and Economics (AUFE) (ACKY1805ZDA).

\begin{abstract}
By conducting an on-line questionnaire survey, the article compared 97 international students' views with 23 Chinese teachers' practices on 8 issues in corrective feedback (CF) in teaching Chinese to speakers of other languages (TCSOL). Results revealed that students' views and teachers' practices conformed to each other in cognition of committing verbal errors, and in whether to correct; that they were mostly incongruent with each other in what to correct; that they were congruent with each other in peer correction, but not in teachers' correction or self-correction; that they coincided with each other in indirect correction, but not in direct one, nor in immediate correction or the maximum correction frequency in one class; and that CF mainly generated positive psychological effects and better learning on students, but its pedagogical efficacy was not evidently approved by the teachers. This research aimed at gaining a deeper insight into the effectiveness of CF in TCSOL to improve the quality of TCSOL.
\end{abstract}

Keywords: CF, TCSOL, students' views, teachers' practices, efficacy

\section{Introduction}

The research on the correlation between $\mathrm{CF}$ and views (beliefs/ attitudes/ preferences) of students and teachers in second language acquisition(SLA) or in foreign language learning and teaching(FLLT) has been conducted for many years by scholars or educators in the world, and a great deal has been achieved(Akiyama, 2017; Cinkara \& Galaly, 2018; Couper, 2019; Horwitz, 1985; Xuan \& Murray, 2020; Zhang \& Rahimi, 2014). Entering the keywords corrective feedback between 1970 to 2020 in Bing Academic, a Microsoft search engine for academics, we obtained 178,000 academic results in English. They covered fields in linguistics, grammar, psychology, pedagogy, pragmatics, cognition, learning disability, computer, etc. and different aspects of learning, such as speaking, writing, listening, and communication, etc.

Students' views and teachers' practices in CF in TCSOL are closely related to the relation between CF and students' and teachers' views in L1 or L2 or FLLT. However, most of the previous researches were concentrated on CF of alphabetic or other languages, few of them were directed at those in the context of TCSOL.

Are students' views of CF congruent with teachers' practices in TCSOL? How effective is CF for students and teachers? What pedagogic implication will this study have for TCSOL, L1, L2 or FLLT? All of these are what we concern.

\section{Review of Literature}

Previous studies have demonstrated that CF types used by teachers tend to influence students' performance. Therefore, knowing how CF is classified is conducive to language learning and teaching. Through combining the most popular and influential data, we teased out three major taxonomies of CF techniques: six-type classification, two-type classification, and x-type classification. 


\subsection{CF Taxonomies}

1. Six-type classification: The most oft-cited six-type classification was put forward by Lyster \& Ranta(1997). They include explicit correction, recasts, clarification requests, metalinguistic feedback, elicitation, and repetition (they initially included in their analysis the seventh type multiple feedback). Of course, the six types are not used evenly, recasts are proven to be mostly used by teachers, although the least likely to lead to uptake of any kind. The six-type classification can also be seen in Ellis's (2009) work, the only difference is that Ellis used paralinguistic signal to replace metalinguistic clues.

2. Two-type classification: The initial six-type classification was then synthesized by Ranta \& Lyster (2007) into two broader categories: reformulations (including recasts and explicit correction) and prompts (including clarification request, metalinguistic feedback, elicitation and repetition). Ellis (2009) differentiated inputproviding (including implicit: recast; explicit: explicit correction) from output-prompting (including implicit: repetition, clarification request; and explicit: metalinguistic explanation, elicitation, and paralinguistic signal). Two-type CF classification is also reflected in explicit and implicit or direct and indirect researches (Baleghizadeh \& Dadashi, 2011; Ellis et al, 2009; Karim \& Nassaji, 2020; Kim et al. 2020; Lyster et al, 2013; Shintani \& Ellis, 2013; Suh, 2014).

3. X-type classification: This is especially used to refer to CF types in TCSOL. We categorize it into $x$-type for the time being because no consensus so far has been reached on the number of CF types in TCSOL. For example, one of the findings in a Chinese as a foreign language classroom by Fu and Nassaji (2016) revealed that there were 12 types of $\mathrm{CF}$.

\subsection{Eight Issues in CF Study}

Horwitz's (1985) study suggests that a systematic assessment of student beliefs would increase student learning and satisfaction in the foreign language methods class. Horwitz's (1988) creation of the well-known Beliefs About Language Learning Inventory (BALLI) questionnaire has greatly stimulated scholars interest in L2 learner beliefs (Loewen et al., 2009). Researches indicate that learners' beliefs in SLA or FLLT might be accountable for learners' behaviors, learning strategies, motivations, and proficiency (Ghabanchi \& Meidani, 2012; Zhu \& Wangle, 2019).

To study students' and teachers' views and CF types is to a certain extent to find clues to the following eight issues based on the early five fundamental issues (Ellis, 2009; Hendrickson, 1978): 1. Whether to correct; 2. What to correct; 3 . Who is to correct; 4 . When to correct; 5 . How to correct; 6 . Which type of CF is the most effective; 7. How often is to correct; and 8. What effects of CF.

Forty-eight thousand two hundred results relevant to the eight issues in CF study between 1970 to 2020 on Bing Academic prove that although the answers to the eight questions are controversial, this does not prevent scholars from researching them. For decades of years, scholars have been revolving around the issue of CF and learners' and teachers' beliefs, attitudes, preferences, views, etc. to explore the correlation between them with the common goal to improve efficacy of L1 or L2 or FLLT.

Whether to correct? For the first question, is it necessary to correct the errors? When unable to recognize their own errors, students need some professional assistance from their teachers. A survey on college students' attitudes toward error correction indicates that students do want to be corrected, and their eagerness to be corrected is more than what teachers feel they should be (Hendrickson, 1978).

What to correct? For this questions, different answers are provided by different scholars or teachers in different classes. Most researchers suggest that teachers should not correct all the errors but correct those that interfere with the meaning of a message or comprehension of the intended meaning of the speaker or writer. Teachers are expected to focus attention on a few error types rather than try to address all the errors learners made (Ellis, 2009). Errors should be corrected when the goal is learning, but not at all times, and it is useless for acquisition (Amara, 2015). Correction of global errors is more crucial than that of local one because it clarifies the intended message more than the correction of several local errors in the same sentence (Burt, 1975). Phonemes and words are what to be corrected in pronunciation (Couper, 2019).

Who is to correct? The third question is about whether it is teachers or learners themselves or peers that should correct the errors. Earlier studies reveal that correcting students' errors is mainly teachers' responsibility (Hendrickson, 1978). But later, being more proficient in pedagogy, teachers do not correct learners' errors all the way. They tend to lead learners to find problems themselves so that they can be aware of the importance of autonomous learning and achieve more. Chandler's (2003) findings indicate that students feel that they learn more from self-correction. Besides, teachers encourage peer correction to let learners to help each other and learn from each other. Sato's (2013) study reveals that positive beliefs lead to positive peer interaction and peer CF. 
When to correct? Concerning this question, the heated debate over immediate or delayed correction has never ceased. Ölmezer-Öztürk \& Öztürk's research (2016) displays that immediate feedback is not felt comfortable, and students are discouraged from speaking in a classroom atmosphere. Amara's (2015) findings show that the timing of correction is determined by the type of errors committed. For pronunciation or grammatical errors, immediate correction is preferable. But for communicative purpose, delayed correction is more preferred. Li et al (2016) find both the immediate and the delayed feedback result in gains in grammaticality judgment test scores, with immediate feedback showing some advantage over delayed feedback.

How to correct? For the fifth question, different correction methods are applied in different situations. Couper (2019) provides diverse correction methods used by participants. Yoshida (2008) finds that teachers choose recasts correction methods because of the time limitation of classes and their awareness of learners' cognitive styles. They also choose elicitation or metalinguistic feedback when they think learners can work out correct forms themselves. However, for most of the learners, they prefer to be able to think about their errors and the correct forms before receiving correct forms by recasts. Cinkara \& Galaly's (2018) finding reveals that students show high preference of specific written feedback to facilitate the correction of mistakes. Omidpour \& Bavali's (2017) study suggests that teachers with normative styles are likely to use oral CF techniques more frequently than those with higher diffuse-avoidant style score.

Which type of $C F$ is the most effective? Concerning this question, the answers also differ from different angles, different learners and teachers. Li's (2010) findings indicate that there is a medium overall effect for CF, and the effect of implicit feedback is better retained than that of explicit feedback. On the other hand, Maleki \& Asl (2015) confirm the efficacy of explicit feedback strategies than that of implicit. Learners who use explanation as an explicit CF strategy achieve higher scores than those who use recast and error code feedback strategies. Ölmezer-Öztürk \& Öztürk (2016) argue that different types of CF might result in quite different students' perceptions. For example, recasts and clarification requests are perceived as ambiguous, and meta-linguistic feedback as anxiety-provoking and difficult to comprehend. Chandler's (2003) study proves that direct correction is best for producing accurate revisions in writing, and students prefer it for its being the fastest and easiest. Masantiah et al (2018) find that different $\mathrm{CF}$ is supposed to be used for different learners considering their basic knowledge.

How often is to correct? By how often is to correct, we mean the frequency of a teacher's maximum correction in one class that is acceptable to both teachers and students. After examining individual versus team differences, Pyke \& Sherlock (2010) find that teams tend to receive a greater amount of CF, whereas individuals require greater motivational feedback (providing motivation to the learner to perform a task or to learn). However, it seems that few researches in the previous studies were on this issue, and it was not singled out for elaboration, but was mingled with whether or which or what to correct.

What effects of CF? Whether CF contributes to L1 or SLA or FLLT is another controversial issue. Much research evidence in L1 or L2 indicates that teachers' feedback focusing principally on correcting the errors is not likely to produce substantive or even measurable improvement in the quality of students' learning (Baleghizadeh \& Dadashi, 2011). Results of devoting much valuable time to correcting students' mistakes may not be satisfactory as was expected (Hendrickson, 1978; Truscott, 2007). Interestingly, some studies in writing have proven the effectiveness of CF in promoting acquisition (Ellis, 2009; Kang \& Han, 2015; Tanveer et al, 2018).

Different from the above studies, this article focused on the major CF issues by making a qualitative and quantitative comparison study between the types of $\mathrm{CF}$ students expect the teacher to use and those teachers actually use in the context of TCSOL, aiming at probing into the depth of CF and contributing to researches in TCSOL, L1, L2 or FLLT.

\section{Research Design}

In this research, the authors used an online questionnaire survey(Note 1) to investigate congruence and incongruence between students' views and teachers' practices in CF in TCSOL.

\subsection{Hypotheses}

$\mathrm{H}_{1}$ : Students' and teachers' cognition of committing verbal errors conform to each other.

$\mathrm{H}_{2}$ : Students' view and teachers' practice in whether to correct conform to each other.

$\mathrm{H}_{3}$ : Students' view and teachers' practice in what to correct conform to each other.

$\mathrm{H}_{4}$ : Students' view and teachers' practice in who is to correct conform to each other.

$\mathrm{H}_{5}$ : Students' view and teachers' practice in when(immediate) to correct conform to each other.

$\mathrm{H}_{6}$ : Students' view and teachers' practice in how to correct conform to each other. 
$\mathrm{H}_{7}$ : Students' view and teachers' practice in how often is to correct conform to each other.

$\mathrm{H}_{8}$ : Students' view and teachers' perception in what effects of CF produces conform to each other.

\subsection{Instrument}

Wen juan xing, an online questionnaire survey software (SPSS) in China was used separately used to distribute, collect and analyze the data of students and teachers. Then, the proportion and correlation analysis between students' views and teachers' practices in CF in TCSOL was further evaluated by Pearson chi-square test accomplished by cross-tabs.

To ensure the validity of the survey, a 5-point Likert scale was used to measure students' views and teachers' practices in CF in TCSOL. Two types of scale were adopted: for students, it was from strongly disagree to strongly agree. For teachers, it was from not true of me at all to always true of me. The reliability coefficient values of students (0.77) and teachers (0.62) are over 0.6. The number of respondents of students(97) and teachers(23) might be one of the major factors that lead to the different results of Cronbach a coefficients.

\subsection{Participants}

Among 97 international students who participated in this questionnaire survey, 54.64\% were male and 45.36\% female. They came from 33 countries all over the world, including Afghanistan, Azerbaijan, Bénin, Burundi, Cambodian, Chile, Congo, Côte d'Ivoire, Dominica, East Timor, Egypt, England, Ethiopia, France, Ghana, Guinea, Guinea Bissau, Indonesia, Kyrgyzstan, Laos, Madagascar, Mexico, Mongolia, Moroccan, Pakistan, Papua New Guinea, Russia, South Africa, South Korea, Thailand, Ukraine, Vanuatu, and Vietnam. Their length of studying Chinese ranged from 5 months to 5 years. A great majority of them were studying in different universities in Anhui Province.

Among 23 Chinese teachers of TCSOL from different universities in Anhui Province, 21.74\% were male and $78.26 \%$ female. Their ages varied from 26 to 60 years old, but $60.87 \%$ were $31 \sim 40$ years old. $69.56 \%$ majored in linguistics, of which $30.44 \%$ in education, and psychology, etc. They taught students at the beginning, intermediate and advanced levels in listening, speaking, reading and writing. Their length of TCSOL was from 0 to 33 years, but $73.91 \%$ had over ten-year teaching experience.

\subsection{Materials}

The questionnaire survey for students comprised three parts. The first part was about demographic data composed of 4 issues: gender, nationality, length of Chinese study, and the university where he or she was learning. The second part was composed of 24 items. It covered the students' cognition of committing verbal errors in Chinese classes, CF 7-W issues in whether, what, who, when, how, how often, and what effects. The third part included 11 items concerning students' psychological responses to CF in Chinese classes and learning effects of CF. In each of the above items, there are five choices for them to choose from: 1 . strongly disagree; 2 . disagree; 3 . not sure; 4. agree; 5. strongly agree.

For teachers, the questionnaire survey contained three parts, too. The first part was also about demographic data composed of 4 issues: gender, age, the major of the final degree, and length of TCSOL. The second part was the same as the students'. The third part included 4 items concerning teaching effects of CF. In each of the above sentences, there are five choices for them to choose from: 1 . It is not true of me at all; 2. It is not true of me; 3 . not sure; 4. It is usually true of me; 5 . It is always true of me.

In the questionnaire, the items of the same category were not arranged in sequence but scattered through the whole questionnaire. Some items were affirmative, some negative to avoid the subjects' inertial choosing, consequently affecting the quality of the survey. But in this article, the items are arranged alphabetically and taxonomically for the sake of convenient reading.

\section{Results and Analysis}

The survey started from November 2018 and ended in January 2019. After 3 months survey, we obtained the valid results from 97 foreign students from all over the world and 23 Chinese teachers. We compared students' views with teachers' practices in $\mathrm{CF}$ in Chinese classes, and obtained the following results.

\subsection{Comparison on the Cognition of Committing Verbal Errors}

The first comparison was about students' and teachers' cognition of committing verbal errors (see Table 1a).

Table 1a. Comparison on the cognition of committing verbal errors \% (N) 


\begin{tabular}{lllllll}
\hline Item & & 1 & 2 & 3 & 4 & 5 \\
\hline It is natural for foreign students to commit & $* \mathrm{~S}$ & $1.03(1)$ & $1.03(1)$ & $10.31(10)$ & $48.45(47)$ & $39.18(38)$ \\
*verbal errors in the process of Chinese & $* \mathrm{~T}$ & $0.00(0)$ & $0.00(0)$ & $0.00(0)$ & $43.48(10)$ & $56.52(13)$ \\
learning. & & & & & &
\end{tabular}

learning.

*S: students; *T: teachers *verbal: spoken and written language

$100 \%$ of teachers against $87.63 \%$ of students thought it natural for foreign students to commit verbal errors in the process of Chinese learning. $10.31 \%$ of students were not sure about that, and $2.06 \%$ disagreed or strongly disagreed to it. But generally, like teachers, a majority of students agreed to it.

Pearson chi-square test was used for further analysis (see Table 1b).

Table 1b. Pearson chi-square test: Comparison on the cognition of committing verbal errors

\begin{tabular}{ll}
\hline Item & Cognition of committing verbal errors \\
\hline Value & $4.259^{\mathrm{a}}$ \\
df & 4 \\
Asymp. Sig.(2-sided) & .372 \\
\hline
\end{tabular}

The result reveals that the asymptotic significance (2-sided) is more than 0.05 , indicating that students' and teachers' cognition of committing verbal errors is not significantly different, hence this result accepts $\mathrm{H}_{1}$.

\subsection{Comparison on Whether to Correct}

Then the authors compared students' view and teachers' practice in whether it is necessary to correct students' verbal errors (see Table 2a).

Table 2a. Comparison on whether to correct $\%(\mathrm{~N})$

\begin{tabular}{lllllll}
\hline Item & & 1 & 2 & 3 & 4 & 5 \\
\hline It is very necessary to correct students' & $\mathrm{S}$ & $0.00(0)$ & $1.03(1)$ & $12.37(12)$ & $51.55(50)$ & $35.05(34)$ \\
verbal errors. & $\mathrm{T}$ & $0.00(0)$ & $0.00(0)$ & $0.00(0)$ & $43.48(10)$ & $56.52(13)$ \\
\hline
\end{tabular}

For the necessity of CF, $86.6 \%$ of students agreed or even strongly agreed to whether to correct. Similarly, $95.65 \%$ of teachers did usually or always practice it.

Pearson chi-square test was used for further analysis (see Table $2 b$ ).

Table 2b. Pearson chi-square test: Comparison on whether to correct

\begin{tabular}{lc}
\hline Item & Whether to correct \\
\hline Value & $4.113^{\mathrm{a}}$ \\
df & 3 \\
Asymp. Sig.(2-sided) & .250 \\
\hline
\end{tabular}

Pearson chi-square test reveals that the asymptotic significance(2-sided) is more than 0.05 , i.e. this result accepts $\mathrm{H}_{2}$.

\subsection{Comparison on What to Correct}

What is to correct? Should all the mistakes or grammar mistakes or the mistakes that interfere with comprehensibility be corrected (see Table 3a)?

Table 3a. Comparison on what to correct $\%(\mathrm{~N})$ 


\begin{tabular}{|c|c|c|c|c|c|c|}
\hline Item & & 1 & 2 & 3 & 4 & 5 \\
\hline $\begin{array}{lcccc}\checkmark & \text { a. } & \text { Teachers } & \text { should correct every }\end{array}$ & $\mathrm{S}$ & $3.09(3)$ & $8.25(8)$ & $11.34(11)$ & $52.58(51)$ & $24.74(24)$ \\
\hline mistake students make. & $\mathrm{T}$ & 21.74(5) & $52.17(12)$ & $8.70(2)$ & $13.04(3)$ & $4.35(1)$ \\
\hline$\checkmark \quad$ b. Teachers should not correct & S & $29.90(29)$ & $37.11(36)$ & $18.56(18)$ & $10.31(10)$ & $4.12(4)$ \\
\hline $\begin{array}{l}\text { students' pronunciation errors in } \\
\text { unless they ins } \\
\text { comprehensibility. interfere }\end{array}$ & $\mathrm{T}$ & $0.00(0)$ & $21.74(5)$ & $43.4(10)$ & $21.74(5)$ & 13.04(3) \\
\hline$\checkmark \quad$ c. Teachers should not correct & $\mathrm{S}$ & $26.80(26)$ & $39.18(38)$ & 17.53(17) & $13.4(13)$ & $3.09(3)$ \\
\hline $\begin{array}{l}\text { students' grammar errors in class unless } \\
\text { they interfere with comprehensibility. }\end{array}$ & $\mathrm{T}$ & $0.00(0)$ & $30.43(7)$ & $39.13(9)$ & $26.09(6)$ & $4.35(1)$ \\
\hline$\checkmark \quad$ d. Teachers should correct students' & $\mathrm{S}$ & $3.09(3)$ & $13.40(13)$ & $37.11(36)$ & 36.08( & $10.31(10)$ \\
\hline common & $\mathrm{T}$ & $0.00(0)$ & $4.35(1)$ & $8.70(2)$ & $60.87(14)$ & $26.09(6)$ \\
\hline$\checkmark \quad$ e. Teachers should correct students' & $\mathrm{S}$ & $1.03(1)$ & $1.03(1)$ & $8.25(8)$ & $61.86(60)$ & $27.84(27)$ \\
\hline oral errors. & $\mathrm{T}$ & $0.00(0)$ & $0.00(0)$ & $26.09(6)$ & $69.56(16)$ & $4.35(1)$ \\
\hline$\checkmark \quad$ f. Teachers should correct students' & $\mathrm{S}$ & $1.03(1)$ & $0.00(0)$ & $5.15(5)$ & $55.67(54)$ & $38.14(37)$ \\
\hline written errors. & $\mathrm{T}$ & $0.00(0)$ & $0.00(0)$ & $0.00(0)$ & 73.91(17) & $26.09(6)$ \\
\hline$\checkmark$ g. Teachers' error correction should & $\mathrm{S}$ & $5.15(5)$ & $12.37(12)$ & 27.84(27) & $48.45(47)$ & $6.19(6)$ \\
\hline focus on grammatical errors. & $\mathrm{T}$ & $0.00(0)$ & 39.13(9) & $43.48(10)$ & $17.39(4)$ & $0.00(0)$ \\
\hline
\end{tabular}

As for $a$, students' view was quite different from teachers' practice. $77.32 \%$ of students expected the teachers to correct every mistake they made, but only $17.39 \%$ of teachers usually or always practiced it. Similarly, in $b$ and $c$, $67.01 \%$ and $65.98 \%$ students expected teachers to correct their pronunciation and grammar mistakes respectively in class even if they did not interfere with comprehensibility, however only $21.74 \%$ and $30.43 \%$ of teachers respectively did so. For $d, 86.96 \%$ of teachers corrected common or habitual errors, but only $46.39 \%$ of students agreed or strongly agreed to them, $37.11 \%$ of students against $8.70 \%$ of teachers were not sure about it. For $e$, compared with $89.70 \%$ of students who agreed or strongly agreed to oral correction, $73.91 \%$ of teachers practiced it. $26.09 \%$ of teachers against $8.525 \%$ of students were not sure about it. But for $f$, the percentage of students' $(93.81 \%)$ view and that of teachers' $(100 \%)$ practice in correcting students' written errors were almost congruent with each other. As to $g, 54.64 \%$ of the students agreed or strongly agreed to focusing on grammatical errors, but only $17.39 \%$ of teachers practiced it. $43.48 \%$ of teachers against $27.84 \%$ of students were not sure about it.

Pearson chi-square test was used for further analysis (see Table $3 b$ ).

Table 3b. Pearson chi-square test: Comparison on what to correct

\begin{tabular}{lccccccc}
\hline Item & $\mathbf{a}$ & $\mathbf{b}$ & $\mathbf{c}$ & $\mathbf{d}$ & $\mathbf{e}$ & $\mathbf{f}$ & $\mathbf{g}$ \\
\hline Value & $41.509^{\mathrm{a}}$ & $17.590^{\mathrm{a}}$ & $12.526^{\mathrm{a}}$ & $12.827^{\mathrm{a}}$ & $10.116^{\mathrm{a}}$ & $3.223^{\mathrm{a}}$ & $15.912^{\mathrm{a}}$ \\
df & 4 & 4 & 4 & 4 & 4 & 3 & 4 \\
Asymp. Sig.(2-sided) & .000 & .001 & .014 & .012 & .039 & .359 & .003 \\
\hline
\end{tabular}

We can see that all the asymptotic significances(2-sided) are less than 0.05 except $f$, indicating that students' view and teachers' practice in what to correct are significantly different in most cases, hence the results accept written errors, but reject $\mathrm{H}_{3}$ in most cases.

\subsection{Comparison on Who is to Correct}

Who is to correct? Is it the teacher or the student himself or herself or the peer that should correct the errors (see Table 4a)?

Table 4a. Comparison on who is to correct $\%(\mathrm{~N})$

\begin{tabular}{|c|c|c|c|c|c|c|}
\hline Item & & 1 & 2 & 3 & 4 & 5 \\
\hline$\checkmark \quad$ a. Students don't like teachers to & $\mathrm{S}$ & 38.14(37) & $38.14(37)$ & $11.34(11)$ & $10.31(10)$ & $2.06(2)$ \\
\hline correct their errors in class. & $\mathrm{T}$ & $0.00(0)$ & $17.39(4)$ & $47.83(11)$ & $17.39(4)$ & $17.39(4)$ \\
\hline$\checkmark \quad$ b. Students' verbal errors should be & $\mathrm{S}$ & $2.06(2)$ & $3.09(3)$ & $17.53(17)$ & $46.39(45)$ & $30.93(30)$ \\
\hline $\begin{array}{l}\text { corrected by teachers because they are } \\
\text { specialists. }\end{array}$ & $\mathrm{T}$ & $8.70(2)$ & $21.74(5)$ & $21.74(5)$ & $39.13(9)$ & $8.70(2)$ \\
\hline
\end{tabular}




\begin{tabular}{lllrrrrr}
\hline$\checkmark \quad$ c. Students prefer to be corrected by & $\mathrm{S}$ & $11.34(11)$ & $26.80(26)$ & $34.02(33)$ & $25.77(25)$ & $2.06(2)$ \\
peers in a small group work rather than by & $\mathrm{T}$ & $0.00(0)$ & $17.39(4)$ & $43.48(10)$ & $30.43(7)$ & $8.70(2)$ \\
the teacher in front of the entire class. & & & & & & \\
$\checkmark \quad \mathrm{d}$ Teachers are supposed to guide & $\mathrm{S}$ & $0.00(0)$ & $2.06(2)$ & $10.31(10)$ & $55.67(54)$ & $31.96(31)$ \\
$\begin{array}{l}\text { students to find the correct answer by } \\
\text { themselves. }\end{array}$ & $\mathrm{T}$ & $0.00(0)$ & $17.39(4)$ & $8.70(2)$ & $34.78(8)$ & $39.13(9)$ \\
\hline
\end{tabular}

The table indicated that $76.28 \%$ of students disagreed or strongly disagreed to $a$, in other words, they preferred teachers' correction. This percentage formed a sharp contrast with that of teachers' (17.39\%). $11.34 \%$ of students against $47.83 \%$ of teachers were not sure about it. $77.32 \%$ of students agreed or strongly agreed to $b$, but only $47.83 \%$ of teachers believed so, and $30.44 \%$ of teachers did not think it true for them. Peer correction in $c$ was agreed or strongly agreed to by $27.83 \%$ of students, and practiced by $39.13 \%$ of teachers. $34.02 \%$ of students against 43.48 of teachers were not sure about it. In $d, 87.63 \%$ of students approved of self-correction, and $73.91 \%$ of teachers practiced it.

Pearson chi-square test was used for further analysis (see Table $4 b$ ).

Table 4b. Pearson chi-square test: Comparison on who is to correct

\begin{tabular}{lrrrr}
\hline Item & a & b & c & d \\
\hline Value & $34.154^{\mathrm{a}}$ & $15.994^{\mathrm{a}}$ & $6.337^{\mathrm{a}}$ & $10.643^{\mathrm{a}}$ \\
df & 4 & 4 & 4 & 3 \\
Asymp. Sig.(2-sided) & .000 & .003 & .175 & .014 \\
\hline
\end{tabular}

It is found that all the asymptotic significances (2-sided) are less than 0.05 except $c$. indicating that students' view and teachers' practice in teachers' correction and self-correction are significantly different, hence the results reject teachers' correction and self-correction, but accept that of peer correction, partially accept $\mathrm{H}_{4}$

\subsection{Comparison on When to Correct}

In this research, delayed $\mathrm{CF}$ was not examined because of the limited length of the paper. The comparison only involved immediate CF in pronunciation, vocabulary, grammar, language use, reading aloud, and answering questions (see Table 5a).

Table 5a. Comparison on immediate CF \% (N)

\begin{tabular}{|c|c|c|c|c|c|c|}
\hline Item & & 1 & 2 & 3 & 4 & 5 \\
\hline immediately & $\mathrm{S}$ & $0.00(0)$ & $5.15(5)$ & $15.46(15)$ & $59.79(58)$ & $19.59(19)$ \\
\hline correct students' errors in class. & $\mathrm{T}$ & $8.70(2)$ & $43.48(10)$ & $34.78(8)$ & 13.04(3) & $0.00(0)$ \\
\hline$\checkmark \quad$ b. Teachers should immediately & $\mathrm{S}$ & $0.00(0)$ & $1.03(1)$ & $9.28(9)$ & $56.70(55)$ & $32.99(32)$ \\
\hline correct students' errors in pronunciation. & $\mathrm{T}$ & $0.00(0)$ & $56.52(13)$ & $4.35(1)$ & $30.43(7)$ & $8.70(2)$ \\
\hline$\checkmark \quad$ c. Teachers should immediately & $\mathrm{S}$ & $0.00(0)$ & $3.09(3)$ & $12.37(12)$ & $58.76(57)$ & $25.77(25)$ \\
\hline correct students' errors in vocabulary. & $\mathrm{T}$ & $0.00(0)$ & $43.48(10)$ & $39.13(9)$ & $17.39(4)$ & $0.00(0)$ \\
\hline$\checkmark \quad$ d. Teachers should immediately & $\mathrm{S}$ & $1.03(1)$ & $3.09(3)$ & 7.22(7) & $58.76(57)$ & $29.90(29)$ \\
\hline correct students' errors in grammar. & $\mathrm{T}$ & $4.35(1)$ & $43.48(10)$ & $26.09(6)$ & $17.39(4)$ & $8.70(2)$ \\
\hline$\checkmark \quad$ e. Teachers should immediately & $\mathrm{S}$ & $0.00(0)$ & $3.09(3)$ & $8.25(8)$ & $62.89(61)$ & $25.77(25)$ \\
\hline correct students' errors in language use. & $\mathrm{T}$ & $4.35(1)$ & $39.13(9)$ & $8.70(2)$ & $39.13(9)$ & $8.70(2)$ \\
\hline$\checkmark \quad$ f. Teachers should immediately correct & $\mathrm{S}$ & $1.03(1)$ & $5.15(5)$ & $15.46(15)$ & $51.55(50)$ & $26.80(26)$ \\
\hline $\begin{array}{l}\text { students' errors in reading aloud even by } \\
\text { interrupting them. }\end{array}$ & $\mathrm{T}$ & $43.48(10)$ & $21.74(5)$ & $26.09(6)$ & $8.70(2)$ & $0.00(0)$ \\
\hline$\checkmark$ g. Teachers should immediately & $\mathrm{S}$ & $3.09(3)$ & $5.15(5)$ & $9.28(9)$ & $55.67(54)$ & $26.80(26)$ \\
\hline $\begin{array}{l}\text { correct students' errors in answering } \\
\text { questions even by interrupting them. }\end{array}$ & $\mathrm{T}$ & $43.48(10)$ & $34.78(8)$ & $21.74(5)$ & $0.00(0)$ & $0.00(0)$ \\
\hline
\end{tabular}

As the table indicated that $79.38 \%$ of students agreed or even strongly agreed to $a$, but only $13.04 \%$ of teachers usually practiced it with zero always practicing it. Likewise, students had stronger views than teachers' practices in immediate correction in all the other errors in their learning process. The percentages of students' views in 
immediate correction in pronunciation $(89.69 \%)$, vocabulary $(84.53 \%)$, grammar $(88.66 \%)$, language use $(88.66 \%)$, and reading aloud $(78.35 \%)$ in $b, c, d, e$, and $f$ were $50.56 \%, 67.14 \%, 62.57 \%, 40.83 \%$, and $69.65 \%$ higher than those of the practices of teachers $(39.13 \%, 17.39 \%, 26.09 \%, 47.83 \%$, and $8.70 \%)$ respectively. For each of the above items the percentages of being not true at all or not true for the teachers reached $56.52 \%, 43.48 \%$, $47.83 \%, 43.48 \%$, and $65.22 \%$ respectively. It was noted that $39.13 \%, 26.09 \%$, and $26.09 \%$ of teachers were not sure whether they should correct students' mistakes immediately respectively in vocabulary, grammar, reading aloud even by interrupting them. None of the teachers corrected students' mistakes immediately even by interrupting them when they were answering questions in $g$, for $78.26 \%$ of teachers it was not true at all or not true, $21.74 \%$ were not sure about it; but a great majority of students $(82.47 \%)$ agreed or strongly agreed to it, only $8.24 \%$ disagreed or strongly disagreed to it.

Pearson chi-square test was used for further analysis (see Table 5b).

Table 5b. Pearson Chi-square Test: Comparison on immediate CF

\begin{tabular}{lrrrrrrr}
\hline Item & $\mathbf{a}$ & $\mathbf{b}$ & $\mathbf{c}$ & $\mathbf{d}$ & $\mathbf{e}$ & $\mathbf{f}$ & $\mathbf{g}$ \\
\hline Value & $46.398^{\mathrm{a}}$ & $55.967^{\mathrm{a}}$ & $47.785^{\mathrm{a}}$ & $44.824^{\mathrm{a}}$ & $32.576^{\mathrm{a}}$ & $57.921^{\mathrm{a}}$ & $64.498^{\mathrm{a}}$ \\
df & 4 & 3 & 3 & 4 & 4 & 4 & 4 \\
Asymp. Sig.(2-sided) & .000 & .000 & .000 & .000 & .000 & .000 & .000 \\
\hline
\end{tabular}

It is found that all the asymptotic significances(2-sided) are less than 0.05 , indicating that students' views on immediate correction are significantly different from the teachers' practices, thus the results reject $\mathrm{H}_{5}$.

\subsection{Comparison on How to Correct}

The sixth comparison was CF type preferred by students and practiced by teachers (see Table 6a).

Table 6a. Comparison on how to correct \% (N)

\begin{tabular}{llrrrrr}
\hline Item & & 1 & 2 & 3 & \multicolumn{1}{c}{4} & \multicolumn{1}{c}{5} \\
\hline$\checkmark \quad$ a. Teachers are supposed to correct & $\mathrm{S}$ & $0.00(0)$ & $5.15(5)$ & $13.4(13)$ & $57.73(56)$ & $23.71(23)$ \\
directly the students' errors. & $\mathrm{T}$ & $0(0)$ & $56.52(13)$ & $17.39(4)$ & $21.74(5)$ & $4.35(1)$ \\
$\checkmark \quad$ b. When a student makes a mistake, the & $\mathrm{S}$ & $7.22(7)$ & $9.28(9)$ & $25.77(25)$ & $41.24(40)$ & $16.49(16)$ \\
best strategy is to say directly, "No, you & $\mathrm{T}$ & $17.39(4)$ & $21.74(5)$ & $39.13(9)$ & $21.74(5)$ & $0.00(0)$ \\
should say...." & & & & & & \\
$\checkmark \quad$ c. Indirect CF is better than direct one, & $\mathrm{S}$ & $5.15(5)$ & $14.43(14)$ & $29.90(29)$ & $32.99(32)$ & $17.53(17)$ \\
for it does not hurt students' self-esteem. & $\mathrm{T}$ & $0.00(0)$ & $8.70(2)$ & $52.17(12)$ & $30.43(7)$ & $8.70(2)$ \\
\hline
\end{tabular}

It was found in $a$ that direct $\mathrm{CF}$ was agreed or strongly agreed to by a great majority of students $(81.44 \%)$, but only $26.09 \%$ of teachers practiced it. $56.52 \%$ teachers did not practice it. $57.73 \%$ of students accepted direct correction in $b$, but only $21.74 \%$ of teachers practiced it, and $39.13 \%$ did not practice it. In $c$, in order not to hurt students' self-esteem, indirect $\mathrm{CF}$ was agreed or strongly agreed to by $50.52 \%$ of students, but practiced by $39.13 \%$ of teachers. $29.90 \%$ of students against $52.17 \%$ of teachers were not sure about it.

Pearson chi-square test was used for further analysis (see Table $6 \mathrm{~b}$ ).

Table 6b. Pearson chi-square test: Comparison on how to correct

\begin{tabular}{llll}
\hline Item & $\mathbf{a}$ & $\mathbf{b}$ & $\mathbf{c}$ \\
\hline Value & $41.136^{\mathrm{a}}$ & $11.423^{\mathrm{a}}$ & $5.298^{\mathrm{a}}$ \\
df & 3 & 4 & 4 \\
Asymp. Sig.(2-sided) & .000 & .022 & .258 \\
\hline
\end{tabular}

It is found that the asymptotic significances (2-sided) in $a, b$ are less than 0.05 , indicating that students' view and teachers' practice in direct correction are significantly different, hence the results reject the direct correction. But 
the asymptotic significance (2-sided) of $c$ is more than 0.05 , indicating it accepts the indirect correction. Therefore, the results partially accept $\mathrm{H}_{6}$.

\subsection{Comparison on How Often is to Correct in One Class}

The seventh comparison was about students' view and teachers' practice in the maximum correction frequency in one class. We provided the options 1-2 times, 3 times, 4 times, 5-10 times, limitless, and not sure for them to choose from (see Table 7a).

Table 7a. Comparison on the maximum CF in one class \% (N)

\begin{tabular}{|c|c|c|c|c|c|c|c|}
\hline Frequency & & $1-2$ & 3 & 4 & $5-10$ & Limitless & Not sure \\
\hline \multirow{2}{*}{$\begin{array}{l}\text { What is your maximum CF in one } \\
\text { class? }\end{array}$} & $\mathrm{S}$ & $13.40(13)$ & $13.40(13)$ & $3.09(3)$ & $31.96(31)$ & $24.74(24)$ & $13.40(13)$ \\
\hline & $\mathrm{T}$ & 21.74(5) & $52.17(12)$ & $0.00(0)$ & $0.00(0)$ & $8.70(2)$ & $17.39(4)$ \\
\hline
\end{tabular}

This table revealed that $73.91 \%$ of teachers' practice in the maximum correction was no more than three, but only $26.80 \%$ of students agreed to it. $31.96 \%$ of students accepted $5-10$ times correction, $24.74 \%$ of them even maintained there should be no limit. The proportion of being not sure was similar to each other.

Pearson chi-square test was used for further analysis (see Table $7 \mathrm{~b}$ ).

Table 7b. Pearson chi-square test: Comparison on the maximum CF in one class

\begin{tabular}{lr}
\hline Frequency & $1-23456-10$ Limitless Not sure \\
\hline Value & $24.757^{\mathrm{a}}$ \\
df & 6 \\
Asymp. Sig.(2-sided) & .003 \\
\hline
\end{tabular}

It is found that the asymptotic significance(2-sided) is less than 0.05 , indicating that students' view and teachers' practice in the maximum correction frequency in one class are significantly different, hence the result rejects $\mathrm{H}_{7}$.

\subsection{Comparison on CF efficacy}

As for this part, it is difficult for the researchers to give the same options for the subjects to choose from because it concerns positive or negative effects of CF on students' psychology and students' learning effects, which quite differ from the actual teaching efficacy confirmed by teachers. Therefore, the data were calculated separately.

\subsubsection{CF Psychological and Learning Effects on Students}

This part concerned students' psychological responses to CF and learning effects (see Table 8).

Table 8. CF psychological and learning effects on Students $\%(\mathrm{~N})$

\begin{tabular}{llllll}
\hline Item & 1 & 2 & 3 & 4 & 5 \\
\hline $\begin{array}{l}\text { Negative response to correction } \\
\text { If the teacher keeps correcting me, I will }\end{array}$ & & & & & \\
\hline$\checkmark \quad$ a. be unwilling to speak. & $32.99(32)$ & $23.71(23)$ & $28.87(28)$ & $8.25(8)$ & $6.29(6)$ \\
$\checkmark \quad$ b. be afraid to speak. Teachers' correction & $42.27(41)$ & $27.84(27)$ & $20.62(20)$ & $7.22(7)$ & $2.06(2)$ \\
in class makes me & & & & & \\
$\checkmark \quad$ c. feel humiliated. & $47.42(46)$ & $28.87(28)$ & $14.43(14)$ & $6.19(6)$ & $3.09(3)$ \\
$\checkmark \quad$ d. feel nervous and anxious. & $47.42(46)$ & $22.68(22)$ & $21.65(21)$ & $7.22(7)$ & $1.03(1)$ \\
$\checkmark \quad$ e. feel shy. & $45.36(44)$ & $19.59(19)$ & $26.80(26)$ & $6.19(6)$ & $2.06(2)$ \\
$\checkmark \quad$ f. be reluctant to answer the questions for a & $43.30(42)$ & $26.80(26)$ & $19.59(19)$ & $8.25(8)$ & $2.06(2)$ \\
$\quad$ period of time. & & & & & \\
\hline $\begin{array}{l}\text { Positive response to correction } \\
\checkmark \quad \text { g. I feel lucky when my teachers correct my }\end{array}$ & $10.31(10)$ & $8.25(8)$ & $24.74(24)$ & $24.74(24)$ & $31.96(31)$ \\
errors in class. & & & & & \\
$\checkmark \quad$ h. I feel grateful to my teacher for & $7.22(7)$ & $4.12(4)$ & $23.71(23)$ & $23.71(23)$ & $41.24(40)$ \\
correcting my errors. & & & & & \\
\hline
\end{tabular}




\begin{tabular}{lllllll}
\hline$\checkmark \quad$ i. I have learnt a lot from teachers' & $1.03(1)$ & $6.19(6)$ & $17.53(17)$ & $49.48(48)$ & $25.77(25)$ \\
corrections of other students' errors. & & & & & \\
$\checkmark \quad$ j. I have learnt a lot from teachers' & $0.00(0)$ & $2.06(2)$ & $15.46(15)$ & $48.45(47)$ & $34.02(33)$ \\
$\begin{array}{l}\text { corrections of my errors. } \\
\checkmark \quad \text { k. Teachers' correction is of great help to }\end{array}$ & $0.00(0)$ & $1.03(1)$ & $6.19(6)$ & $54.64(53)$ & $38.14(37)$ \\
my Chinese learning.
\end{tabular}

We assumed that teachers' keeping correcting would make students unwilling to speak or afraid to speak. However, the results in $a$ and $b$ showed that $56.7 \%$ and $70.11 \%$ of students disagreed or strongly disagreed to them respectively. We assumed that teachers' correction would make students feel humiliated, nervous and anxious, shy, and even reluctant to answer the questions for a period of time. On the contrary, $76.29 \%, 70.10 \%, 64.95 \%$ and $70.10 \%$ in $c, d, e$, and $f$ disagreed or strongly disagreed to it respectively. What's more, $56.70 \%$ felt lucky when their teachers corrected their errors in class, and $64.95 \%$ felt grateful to their teacher for correction, as were revealed in $g$ and $h$. From $i, j$ and $k$, it was learned that students learnt much whether from teachers' correction of other students' mistakes(75.25\%) or from teachers' correction of their own mistakes(82.47\%). Teachers' correction is beneficial to students' Chinese learning(92.78\%). In other words, these results showed that CF mainly produces positive psychological effects and better learning on students.

\subsubsection{CF Teaching Effects by Teachers}

As for CF efficacy conformed by teachers in Chinese classes, we focused on the actual effect of CF in the teaching process. Will students commit the same mistakes after correction (see Table 9)?

Table 9. CF Teaching Effects by Teachers \%(N)

\begin{tabular}{llllll}
\hline Item & 1 & 2 & 3 & 4 & 5 \\
\hline$\checkmark \quad$ a. After correction, students would not & $13.04(3)$ & $47.83(11$ & $21.74(5)$ & $17.39(4)$ & $0.00(0)$ \\
$\begin{array}{l}\text { answer the questions enthusiastically. } \\
\checkmark \quad \text { b. I try in vain to correct students' mistakes }\end{array}$ & $4.35(1)$ & $39.13(9)$ & $43.48(10)$ & $13.04(3)$ & $0.00(0)$ \\
$\begin{array}{l}\text { in class because they will be repeated } \\
\checkmark \quad \text { c. The mistakes I have corrected are not }\end{array}$ & $0.00(0)$ & $13.04(3)$ & $47.83(11)$ & $39.13(9)$ & $0.00(0)$ \\
$\begin{array}{l}\text { repeated in class, but are after class. } \\
\checkmark \quad \text { d. The mistakes I have corrected in class are }\end{array}$ & $4.35(1)$ & $26.09(6)$ & $52.17(12)$ & $17.39(4)$ & $0.00(0)$ \\
not repeated in class. & & & & \\
\hline
\end{tabular}

As $a$ indicated that $60.87 \%$ did not think that CF would affect students enthusiasm in answering the questions although $21.74 \%$ were not sure of it, and $17.39 \%$ approved it. $b$ displayed that $13.04 \%$ of teachers thought that CF was useless, and students would repeat the mistakes. But $43.48 \%$ were not sure about it, and less than half of the teachers (43.48\%) didn't think it true to them. $c$ indicated that $39.13 \%$ believed that the mistakes were not repeated in class, but were repeated after class. However, $47.83 \%$ were not sure about it. $13.04 \%$ didn't think it true at all for them. $d$ revealed that only $17.39 \%$ of teachers believed that students would not repeat the corrected mistake, $52.17 \%$ were not sure of it, and $30.44 \%$ did not approve it. The results suggested that it was still not certain that $\mathrm{CF}$ was very pedagogically effective, and students would not repeat the mistakes after correction. Therefore, the results in 4.8.1 and 4.8.2 partially accept $\mathrm{H}_{8}$.

\section{Discussion}

Results revealed that both students and teachers conformed to each other in cognition of committing verbal errors in the process of Chinese learning. They were congruent with each other in whether to correct, which confirmed the results in the early study (Hendrickson, 1978). However, students' views and teachers' practices in what to correct were quite different in many aspects. Most students (77.32\%) hoped that teachers could correct every mistake whether they interfered with comprehensibility or not, but only $17.39 \%$ of teachers practiced it. A great majority of teachers (86.98\%) just focused on common or habitual errors. More students (54.64\%) than teachers $(17.39 \%)$ paid attention to correcting grammatical errors. Of course, they coincided with each other in written errors. These results considerably matched those controversial researches in early times (Ellis, 2009). As for who is to correct, most students preferred teachers' correction, but fewer teachers practiced it. More students than teachers approved self-correction. Although they consisted with each other in peer correction, the percentages of view $(27.83 \%)$ and practice $(39.13 \%)$ were not high. These results agreed to some extent with those in the previous 
studies (Chandler, 2003; Ellis, 2009; Hendrickson, 1978; Sato, 2013). With regard to when to correct, students' view on immediate correction were significantly different the teachers' practice. Most students preferred immediate correction. As far as how to correct is concerned, it is a very complicated issue, for it could be understood in a broad or narrow sense. In the broad sense, it refers to direct or indirect CF. But in the narrow sense, it involves specific CF methods and teachers' attitudes. In this study, broadly speaking, students and teachers consisted with each other in indirect correction, but not in direct one. Practically, how to correct is contingent on the type of courses, the level of learners, the beliefs of learners and teachers. This result agreed with the earlier researches, too. In terms of the maximum correction frequency in one class, students' view and teachers' practice were also measurably different. $73.91 \%$ of teachers' practice in the maximum correction was no more than three, but $56.65 \%$ of students accepted $5-10$ times correction or limitless correction. As for the CF efficacy, from both students' and teachers' perspectives, CF mainly generated positive psychological effects and better learning effects on students, but it did not prove distinctly that CF was very effective, and students would not repeat the mistakes after correction.

\section{Pedagogic Implications}

Based on the results discussed above, the present study on CF might have implications for TCSOL, L1, L2 or FLLT. To satisfy students' CF need and minimize their repetition of mistakes, it is suggested that teachers correct as many mistakes as possible. Next, compared with peer correction, most students preferred teachers' correction because they were considered authoritative and their corrections tended to be reliable. Thus teachers are suggested to spend more time in CF. Besides, since self-correction under teachers' guidance was welcomed by the majority of students, it should be practiced more in and after class. Furthermore, most students reported a preference for immediate correction of pronunciation, vocabulary, grammar, language use, reading aloud and answering questions without caring about being interrupted, such results may eliminate teachers' uncertainty about when to correct mistakes or reduce their delay in immediate correction. Finally, as to frequency of CF, teachers can perform 5-10 times correction or even more in one class period without worrying that it would result in negative effects of CF.

\section{Limitations and Prospective Researches}

This article compared students' views with teachers' practices in CF in the context of TCSOL. As CF is an indispensable part in the process of teaching, our findings may be of some help to TCSOL, L1, L2 and FLLT.

But there are still some limitations in the research. Firstly, the research methodology was simple. It was only based on the network survey, lacking of class observations or students' performances. As a result, the most effective type of $C F$ was not examined. Secondly, it just involved part of the contents in CF research for the limited length of the survey, and it did not cover all the detailed or specific issues. For instance, delayed correction was not involved. Thirdly, students at different levels and teachers teaching different courses were mixed together to compare, they were not divided into groups according to levels and courses. This might influence the results of the survey. Finally, cultural factors were not covered to go into the deeper side of the research.

Prospective researches may require diverse research methods and more detailed design to explore the relationships between students' views with teachers' practices in CF in the context of TCSOL. They can be interdisciplinary, taking more psychological and cultural factors into account, instead of a pedagogical longitude study.

\section{Conclusion}

To learn or teach a foreign language or L2 well is a hard journey. SLA study reveals that result of L2 acquisition is an implicit system, which concerns the "mental representation". Instruction can only affect explicit knowledge, but acquisition involves the development of implicit knowledge, and few scholars, if any, believe that explicit knowledge turns into implicit knowledge (VanPatten et al., 2020: 237, 288). Hence to improve the efficacy of CF and the quality of language learning and teaching, there is still a long way to go.

\section{References}

Akiyama, Y. (2017). Learner beliefs and corrective feedback in telecollaboration: A longitudinal investigation. System, 64, 58-73. https://doi.org/10.1016/j.system.2016.12.007

Amara, N. (2015). Errors correction in foreign language teaching. The Online Journal of New Horizons in Education, 5(3), 58-68.

Baleghizadeh, S., \& Dadashi, M. (2011). The effect of direct and indirect corrective feedback on students' spelling errors. Profile, Bogotá, Colombia, 13(1), 129-137.

Burt, K. M. (1975). Error analysis in the adult EFL classroom. TESOL Quarterly, 9, 53-63. 
https://doi.org/10.2307/3586012

Chandler, J. (2003). The efficacy of various kinds of error feedback for improvement in the accuracy and fluency of L2 student writing. Journal of Second Language Writing, 12(3), 267-296. https://doi.org/10.1016/S10603743(03)00038-9

Cinkara, E., \& Galaly, F. J. (2018). EFL students' and teachers' attitudes towards written Feedback in writing classes: A case of Iraqi high-schools. I-manager's Journal on English Language Teaching, 8(1), 44-55. https://doi.org/10.26634/jelt.8.1.13947

Couper, G. (2019). Teachers' cognitions of corrective feedback on pronunciation: Their beliefs, perceptions and practices. System, 84, 41-52. https://doi.org/10.1016/j.system.2019.04.003

Ellis, R. (2009). Corrective feedback and teacher development, L2 Journal, 1, 3-18. https://doi.org/10.5070/12.v1i1.9054

Ellis, R., Loewen, S., \& Erlam, R. (2009). Implicit and explicit knowledge in second language learning, testing and teaching. Clevedon, North Somerset: United Kingdom: Multilingual Matters. https://doi.org/10.21832/9781847691767-016

Fu, T. F., \& Nassaji, H. (2016). Corrective feedback, learner uptake, and feedback perception in a Chinese as a foreign language classroom. Studies in Second Language Learning and Teaching, 6(1), 159-181. https://doi.org/doi: 10.14746/ssllt.2016.6.1.8

Ghabanchi, Z., \& Meidani, E. N. (2012). Beliefs about language learning and strategy use: The case of Iranian non-English majors. World Journal of English Language, 2(1), 21-30. https://doi.org/10.5430/wjel.v2n1p21

Hendrickson, J. M. (1978). Error correction in foreign language teaching: Recent theory, research, and practice. Modern Language Journal, 62(8), 387-398. https://doi.org/10.1111/j.1540-4781.1978.tb02409.x

Horwitz, E. K. (1985). Using student beliefs about language learning and teaching in the foreign language methods course. Foreign Language Annals, 18, 333-340. https://doi.org/10.1111/j.1944-9720.1985.tb01811.x

Horwitz, E. K. (1988). The beliefs about language learning of beginning university foreign language students. Modern Language Journal, 72(3), 283-294. https://doi.org/10.1111/j.1540-4781.1988.tb04190.x

Kang, E. Y., \& Han, Z. H. (2015). The efficacy of written corrective feedback in improving L2 written accuracy: A meta-analysis. The Modern Language Journal, 99(1), 1-18. https://doi.org/10.1111/modl.12189

Karim, K., \& Nassaji, H. (2020). The revision and transfer effects of direct and indirect comprehensive corrective feedback on ESL students' writing. Language Teaching Research, 24(4), 519-539. https://doi.org/10.1177/1362168818802469

Kim, Y. J., Choi, B., Kang, S., Kim, B., \& Yun, H. (2020). Comparing the effects of direct and indirect synchronous written corrective feedback: Learning outcomes and students' perceptions. Foreign Language Annals, 53(1), 176-199. https://doi.org/10.1111/flan.12443

Li, S. F. (2010). The effectiveness of corrective feedback in SLA: A meta-analysis. Language Learning, 60(2), 309-365. https://doi.org/10.1111/j.1467-9922.2010.00561.x

Li, S., Zhu, Y., \& Ellis. R. (2016). The Effects of the timing of corrective feedback on the acquisition of a new linguistic structure. The Modern Language Journal, 100(1), 276-295. https://doi.org/10.1111/modl.12315

Loewen, S., Li, S. F., FEI, F., Thompson, A., Nakatsukasa, K., Ahn, S., \& Chen, X. Q. (2009). Second language learners' beliefs about grammar instruction and error correction. The Modern Language Journal, 93(1), 91104. https://doi.org/10.1111/j.1540-4781.2009.00830.x

Lyster, R., \& Ranta, L. (1997). Corrective feedback and learner uptake. Studies in Second Language Acquisition, 19, 37-66. https://doi.org/10.1017/S0272263197001034

Lyster, R., Saito, K., \& Sato, M. (2013). Oral corrective feedback in second language classrooms. Language Teaching, 46(1), 1-40. https://doi.org/10.1017/S0261444812000365

Maleki, N. A., \& Asl, H. D. (2015). A comparison study of the effects of implicit and explicit corrective feedback on EFL learners levels of grammatical accuracy. English Literature \& Language Review, 2(8), 82-88.

Masantiah, C., Pasiphol, S., \& Tangdhanakanond, K. (2018). Student and feedback: Which type of feedback is preferable? Kasetsart Journal of Social Sciences, 1-6. https://doi.org/10.1016/j.kjss. 2018.07.020

Ölmezer-Öztürk, E., \& Öztürk, G. (2016). Types and timing of oral corrective feedback in EFL classrooms: Voices 
from students. Novitas-ROYAL (Research on Youth and Language), 10(2), 113-133.

Omidpour, E., \& Bavali, M. (2017). The relationship between frequency of oral corrective feedback and identity processing style among Iranian EFL teachers. Journal of Studies in Learning and Teaching English, 6(1), 2345.

Pyke, J. G., \& Sherlock, J. J. (2010). A closer look at instructor-student feedback online: A case study analysis of the types and frequency. MERLOT Journal of Online Learning and Teaching, 6(1), 110-121.

Ranta, L., \& Lyster, R. (2007). A cognitive approach to improving immersion students' oral language abilities: The awareness-practice-feedback sequence. In R. DeKeyser (Ed.), Practice in a second language: Perspectives from applied linguistics and cognitive psychology. Cambridge: Cambridge University Press, 141-160. https://doi.org/10.1017/CBO9780511667275.009

Sato, M. (2013). Beliefs about peer interaction and peer corrective feedback: Efficacy of classroom intervention. The Modern Language Journal, 97(3), 611-633. https://doi.org/10.1111/j.1540-4781.2013.12035.x

Shintani, N., \& Ellis, R. (2013). The comparative effect of direct written corrective feedback and metalinguistic explanation on learners' explicit and implicit knowledge of the English indefinite article. Journal of Second Language Writing, 22(3), 286-306. https://doi.org/10.1016/j.jslw.2013.03.011

Suh, B. (2014). The effectiveness of direct and indirect coded written feedback in English as a foreign language. Second Language Research, 50(3), 795-814.

Tanveer, A., Malghani, M., Khosa, D., \& Khosa. M. (2018). Efficacy of written Corrective feedback as a tool to reduce learners' errors on L2 writing. International Journal of English Linguistics, 8(5), 166-180. https://doi.org/10.5539/ijel.v8n5p166

Truscott, J. (2007). The effect of error correction on learners' ability to write accurately. Journal of Second Language Writing, 16, 255-272. https://doi.org/10.1016/j.jslw.2007.06.003

VanPatten, B., Smith, M., \& Benati, A. G. (2020). Key Questions in Second Language Acquisition. Cambridge/ New York/Port Melbourne/New Delhi / Singapore: Cambridge University Press. https://doi.org/10.1017/9781108761529

Xuan, V. H., \& Murray J. C. (2020). Corrective feedback: Beliefs and practices of Vietnamese primary EFL teachers. Language Teaching Research, 1-31. https://doi.org/10.1177/1362168820931897

Yoshida, R. (2008). Teachers' choice and learners' preference of corrective feedback types. Language Awareness, 17(1), 78-93. https://doi.org/10.2167/la429.0

Zhang, L. J., \& Rahimi, M. (2014). EFL learners' anxiety level and their beliefs about corrective feedback in oral communication classes. System, 42, 429-439. https://doi.org/10.1016/j.system.2014.01.012

Zhu, Y., \& Wang, B. L. (2019). Investigating English language learners' beliefs about oral corrective feedback at Chinese universities: A large-scale survey, Language Awareness, 28(2), 139-161. https://doi.org/10.1080/09658416.2019.1620755

\section{Note}

Note 1. In this questionnaire survey, the question items in Wu's(2020) research were used.

$\mathrm{Wu}$, Liqin (2020). Gender and learners' beliefs in corrective feedback in learning Chinese as a foreign language: A network questionnaire survey report. International Educational Research, 3(4), 1-9. https://doi.org/10.30560/ier.v3n4p1

\section{Copyrights}

Copyright for this article is retained by the author(s), with first publication rights granted to the journal.

This is an open-access article distributed under the terms and conditions of the Creative Commons Attribution license (http://creativecommons.org/licenses/by/4.0/). 